Ria Astuti, Neneng Martini, Sharon Gondodiputro, Merry Wijaya, Ariyati Mandiri

\title{
RISIKO FAKTOR IBU TERHADAP KEJADIAN STUNTING
}

\author{
Ria Astuti ${ }^{1}$, Neneng Martini ${ }^{2}$, Sharon Gondodiputro ${ }^{3}$, Merry Wijaya ${ }^{4}$, Ariyati Mandiri ${ }^{5}$ \\ 1,3,4,5Departemen IImu Kesehatan Masyarakat, Fakultas Kedokteran, Universitas Padjadjaran, \\ 2Program Studi Diploma IV Kebidanan Fakultas Kedokteran Universitas Padjadjaran \\ Korespondensi email : neneng_martini@yahoo.co.id
}

\section{ABSTRACT MOTHER'S RISK FACTOR BASED ON STUNTING INCIDENT}

Background: Stunting is one of the nutritional problems experienced by todders in the world today. According to RISKESDAS data in 2018, the incidence of stunting in indonesia wasa $29,9 \%$. in west java $29,9 \%$, in Sumedang regency 41,08\%, and in the Jatinangor Puskesmas working area in 2019 there were 381 stunting children.

Purpose: The purpose of this study is to analyze the relationship between maternal risk factors and the incidence of stunting in the working area of the Jatinangor Comunity Health Center.

Methods: This research is a quantitative study with an analytical research design with a case control approach. The cases in this study werw children with stunting and control, namely children who were not stunting. Sampling was carried out by proportional stratified random sampling for stunting infants and for non-stunting samples according to stunting infants (1:1) with a samples size of 154 respondents. Data was collected by measuring the height of children under five, filling in the questionnare and looking at the history of anemia during pregnancy in the chi-square test.

Results: The results showed that maternal factors such as: mother's age, mother's education, how many children, history of exclusive breastfeeding, history of anemia during pregnancy obtained $p$ value 0.05 which indicates there is no relationship and there is no significant risk and maternal factors such as work. obtained $p$ value $<0.05$ which indicates there is a relationship and there is a large risk, namely 2.6 times compared to mothers who do not work.

Conclusion: There is no significant relationship and risk between maternal age, mother's education, how many children, history of exclusive breastfeeding, history of anemia in pregnant women, the incidence pf $p>0,05$ for each variable, and there is a relationship between maternal work and the incidence of stunting with $p<0,05$ $(p=0,009<0,005)$ and there is a risk of stunting in working mothers with 2,6 times compared to mothers who do not work.

Suggestion: Future researchers are expected to be able to further examine what types of mother's work can affect stunting and examine more deeply about who the child's parenting pattern is assigned to and the last education of the caregiver of the child, not only the last education of the mother.

Keywords: risk factors, stunting, toddlers

\section{ABSTRAK}

Latar Belakang: Kejadian balita pendek atau sering disebut sebagai stunting merupakan salah satu masalah gizi yang dialami oleh balita di dunia saat ini. Menurut data Riset Kesehatan Dasar (Riskesdas) 2018 angka kejadian stunting di Indonesia terdapat 29,9\%. ${ }^{1}$ Di Jawa Barat 29,9\%, di Kabupaten Sumedang angkanya masih cukup tinggi yaitu sebesar $41,08 \%$, dan berdasarkan data yang didapatkan di Kecamatan Jatinangor wilayah kerja Puskesmas pada tahun 2019 terdapat 381 balita stunting.

Tujuan: Menganalisis hubungan antara faktor risiko ibu dengan kejadian stunting di wilayah kerja Puskesmas Jatinangor Kabupaten Sumedang.

Metode: Penelitian ini merupakan penelitian kuantitatif dengan desain penelitian analitik dengan pendekatan kasus kontrol. Kasus dalam penelitian ini yaitu balita stunting dan kontrol yaitu balita non stunting. Sebanyak total 154 sampel yaitu 77 balita stunting dan 77 balita non stunting. Pengambilan sampel dilakukan dengan proportional stratified random sampling untuk balita stunting dan untuk sampel non stunting menyesuaikan dari balita stunting (1:1). Pengumpulan data dilakukan dengan melakukan pengukuran tinggi badan balita, mengisi lembar pertanyaan serta melihat riwayat anemia ibu saat hamil dibuku KIA. Analisis data bivariat menggunakan uji chi-square. 


\section{JKM (Jurnal Kebidanan Malahayati),Vol 7,No.4.Oktober 2021, ISSN (Print) 2476-8944 ISSN (Online) 2579-762X, Hal 842-850}

Hasil: Hasil penelitian menunjukkan bahwa faktor ibu seperti: usia ibu, pendidikan ibu, anak keberapa, riwayat ASI ekslusif, riwayat anemia pada ibu saat hamil memperoleh nilai $p>0,05$ yang menunjukkan tidak terdapat hubungan dan tidak terdapat risiko yang signifikan dan faktor ibu seperti pekerjaan didapatkan nilai $p<$ 0,05 yang menunjukkan terdapat hubungan dan terdapat besar risiko yaitu 2,6 kali dibanding ibu yag tidak bekerja.

Kesimpulan: Tidak terdapat hubungan dan risiko yang signifikan antara usia ibu, pendidikan ibu, anak keberapa, riwayat ASI eksklusif, riwayat anemia pada ibu hamil terhadap kejadian dengan diperoleh nilai $p>0,05$ dari masing-masing varibel, dan terdapat hubungan antara pekerjaan ibu terhadap kejadian stunting dengan nilai $p<0,05(p=0,009<0,05)$ serta terdapat risiko kejadian stunting pada ibu bekerja 2,6 kali dibanding ibu yang tidak bekerja.

Saran: Peneliti selanjutnya diharapkan dapat meneliti lebih lanjut mengenai jenis pekerjaan ibu seperti apa yang dapat mempengaruhi stunting dan mengkaji lebih mendalam mengenai pola asuh anak diserahkan kepada siapa dan pendidikan terakhir pengasuh dari anak tersebut, bukan hanya pendidikan terakhir dari ibunya.

Kata Kunci : faktor risiko, stunting, balita

\section{PENDAHULUAN}

Menurut World Health Organization (WHO) data prevalensi balita stunting, Indonesia termasuk ke dalam Negara ke-3 dengan prevalensi tertinggi di regional Asia Tenggara /South-East Asia Regional (SEAR). Rata-rata prevalensi balita stunting di Indonesia tahun 2005-2017 adalah $36,4 \% .{ }^{2}$ Pada tahun 2018, menurut data Riset Kesehatan Dasar (Riskesdas) angka kejadian stunting di indonesia terus menurun hingga 29,9 persen, dengan kriteria sangat pendek yaitu sebesar 12,8 \% dan pendek sebesar 17,1\%. ${ }^{1} \mathrm{Di}$ Jawa Barat angka kejadian stunting yaitu $29,9 \%$, sedangkan di Kabupaten Sumedang angkanya masih cukup tinggi yaitu sebesar $41,08 \%$, dan berdasarkan data yang didapatkan di Kecamatan Jatinangor wilayah kerja Puskesmas pada tahun 2019 terdapat 381 balita stunting yang tersebar di 7 desa yaitu Desa Cikeruh, Hegarmanah, Cipacing, Cibeusi, Sayang, Cileles, Cilayung. hal ini dapat disimpulkan bahwa angka kejadian stunting masih cukup tinggi. ${ }^{3}$

Stunting dapat menyebabkan penurunan kemampuan motorik dan kognitif serta penurunan performa kerja. Balita stunting memiliki rata-rata skor Intelligence Quotient (IQ) sebelas poin lebih rendah dibandingkan rata-rata skor intelligence Quotient (IQ) pada balita normal, dan perkembangan mental kurang optimal serta status kesehatan anak sering terganggu yaitu anak rentan terhadap penyakit baik menular maupun penyakit tidak menular seperti anak tumbuh menjadi dewasa yang rentan dengan penyakit penyakit jantung koroner,obesitas, hipertensi, dan osteoporosis. ${ }^{4}$

Stunting pada anak merupakan konsekuensi dari beberapa faktor termasuk gizi makronutrien dan mikronutrien: seperti protein, zat besi, zink, kalsium, vitamin $D, A$ serta $C$, faktor lain frekuensi pemberian MP-ASI yang kurang dan pemberian MP-ASI/susu formula terlalu dini, adapun beberapa faktor yang dapat mempengaruhi terjadinya stunting yaitu riwayat anemia pada ibu hamil, usia ibu, pekerjaan ibu, pendidikan ibu, anak keberapa serta ASI eksklusif selain itu menurut penelitian Afiska dkk (2019) bahwa terdapat hubungan antara pekerjaan ibu terhadap kejadian stunting. Berdasar atas hasil penelitian Eko Setiawan dkk Stunting pada anak merupakan dampak dari defisiensi nutrisi selama seribu hari pertama kehidupan. ${ }^{5,6}$ Menurut Wahida dkk, faktor gizi ibu sebelum dan selama kehamilan merupakan penyebab tidak langsung yang memberikan kontribusi terhadap pertumbuhan dan perkembangan janin, gangguan gizi pada kehamilan yaitu anemia. ${ }^{7}$ Anemia pada ibu hamil merupakan salah faktor ibu yang dapat mempengaruhi stunting yaitu keadaan massa hemoglobin atau eritrosit yang beredar tidak dapat memenuhi fungsinya untuk menyediakan oksigen yang akan dialirkan ke seluruh tubuh termasuk untuk janin jika oksigen ke jaringan tulang janin berkurang maka tulang tidak akan tumbuh maksimal, dikatakan penurunan hemoglobin adalah jika dihitung eritrosit dibawah normal. Ibu hamil dapat didiagnosis anemia jika kadar hemoglobin di bawah $11 \mathrm{gr} / \mathrm{dl}^{2}$ pada trimester 1 dan 3, di bawah 10,5 gr/dl2 pada trimester 2. ${ }^{8}$ Menurut World Health Organization (WHO) prevalensi ibu hamil yang mengalami defisiensi besi sekitar 35-75\%, sedangkan Di Indonesia prevalensi anemia pada ibu hamil tahun 2018 sekitar 48,9\%.

Berdasarkan hasil penelitian erna kusumawati bahwa faktor ibu menunjukkan hubungan bermakna (nilai $p<0,05$ ) yaitu 
pengetahuan ibu yang kurang baik berisiko meningkatkan 3,27 kali lebih besar kejadian stunting dibandingkan dengan pengetahuan ibu yang yang baik. ${ }^{5}$ Pendidikan ibu sangat penting karena ibu harus mempunyai pengetahuan tentang gizi sehingga pemenuhan gizi keluarga khususnya anak dapat tercapai, karena ibu dengan pendidikan rendah akan sulit menyerap informasi gizi dan anak lebih berisiko mengalami stunting, usia ibu hamil $\leq 20$ tahun dan $\geq 35$ tahun komplikasi kehamilan akan lebih mudah terjadi sehingga akan berdampak pada pertumbuhan dan perkembangan janin. ${ }^{9}$ Stunting terjadi karena dampak kurang gizi selama 1000 HPK sehingga ASI ekslusif sangat penting karena ASI sangat baik untuk membantu pertumbuhan dan perkembangan anak. Berdasarkan hasil penelitian Sri mugianti bahwa Di Indonesia, perilaku ibu dalam pemberian ASI ekslusif memiliki hubungan yang bermakna dengan indeks PB/U (Panjang Badan menurut Umur). penelitian ini bertujuan untuk menganalisis hubungan antara faktor-faktor risiko ibu dengan kejadian stunting di wilayah kerja Puskesmas Jatinangor Kabupaten Sumedang.

\section{METODE PENELITIAN}

Penelitian ini merupakan penelitian kuantitatif dengan desain penelitian analitik dengan pendekatan kasus kontrol. Kasus dalam penelitian ini yaitu balita stunting dan kontrol yaitu balita non stunting.

Penelitian ini berlokasi di wilayah kerja Puskesmas Jatinangor Kabupaten Sumedang yaitu di Desa Cikeruh, Hegarmanah, Cipacing, Cibeusi, Sayang, Cileles, Cilayung dengan jumlah sampel penelitian 154 responden yaitu 77 balita stunting dan 77 balita non stunting. Pengambilan sampel dilakukan dengan proportional stratified random sampling untuk balita stunting dan untuk sampel non stunting menyesuaikan dari balita stunting $(1: 1)$ dengan kriteria inklusi: Ibu dari balita yang dijadikan responden, berdomisili di Kecamatan Jatinangor, ibu dapat membaca dan menulis, ibu dapat mengerti Bahasa Indonesia, bersedia menjadi responden, balita berusia $\geq 24$ bulan sd 60 bulan pada saat pengambilan sampel. balita berdomisili di Kecamatan Jatinangor, balita bersedia menjadi subjek penelitian.

Pengambilan data penelitian dilaksanakan pada bulan September 2020 yang sebelumnya sudah dilakukan izin penelitian terlebih dahulu yang diperoleh dari dua instansi yaitu Dinas Kesehatan Kabupaten Sumedang dan Puskesmas Jatinangor. Penelitian ini telah mendapat izin etik dari Komite Etik Universitas Padjadjaran Bandung,
Indonesia berdasarkan izin etik 775 / UN6. KEP / EC / 2020.

Pengambilan sampel diawali dengan melihat daftar stunting terlebih dahulu di Puskesmas Jatinangor selanjutnya mendatangi setiap rumah balita yang terdapat di 7 desa Kecamatan Jatinangor dilakukan dengan cara door to door dan untuk sampel balita non stunting menyesuaikan umur dan jumlah balita stunting (matching) sampai memenuhi sampel yang dibutuhan, sebelum penelitian dilaksanakan peneliti melakukan inform consent terlebih dahulu jika ibu dan balita menyetujui maka dilanjutkan proses pengambilan data dengan mengukur tinggi badan balita untuk memastikan apakah balita stunting atau tidak serta membagi lembar pertanyaan dan melihat hemoglobin ibu saat hamil di buku KIA.

Data dianalisis dengan analisis univariat untuk mengetahui gambaran distribusi frekuensi, analisis bivariat menggunakan uji chi square.

\section{HASIL DAN PEMBAHASAN}

Faktor ibu terdiri dari: usia ibu saat hamil, pendidikan ibu, anak keberapa, riwayat anemia saat hamil, ASI eksklusif serta pekerjaan ibu. Gambaran faktor ibu dan balita stunting di wilayah kerja Puskesmas Jatinangor dengan menggunakan distribusi frekuensi seperti yang dijelaskan pada tabel berikut:

Tabel 1.

Distribusi Frekuensi Faktor lbu

\begin{tabular}{lcc}
\hline \multicolumn{1}{c}{ Faktor Ibu } & F & $\%$ \\
\hline Usia Ibu Saat Hamil & & \\
$<$ 20 Tahun & 16 & 10.4 \\
20-35 Tahun & 111 & 72.0 \\
>35 Tahun & 27 & 17.6 \\
Pendidikan Ibu & & \\
Tidak Sekolah & 0 & 0 \\
SD & 27 & 17.5 \\
SMP & 56 & 36.4 \\
SMA & 58 & 37.7 \\
PT & 13 & 8.4 \\
Anak Ke & & \\
1 & 50 & 32.5 \\
2 & 50 & 32.5 \\
3 & 32 & 20.8 \\
4 & 14 & 9.1 \\
5 & 7 & 4.5 \\
6 & 1 & 0.6 \\
Riwayat Anemia Saat Hamil & & \\
Anemia & 32 & 20.8 \\
Tidak anemia & 122 & 79.2 \\
ASI Eksklusif & &
\end{tabular}


JKM (Jurnal Kebidanan Malahayati),Vol 7,No.4.Oktober 2021,

ISSN (Print) 2476-8944 ISSN (Online) 2579-762X, Hal 842-850

\begin{tabular}{lcc} 
ASI Eksklusif & 108 & 70.0 \\
Tidak ASI Eksklusif & 46 & 30.0 \\
Pekerjaan lbu & & \\
Bekerja & 47 & 30.5 \\
Tidak bekerja & 107 & 69.5 \\
\hline
\end{tabular}

Berdasarkan table 1 dari total 154 sampel terdapat mayoritas usia ibu saat hamil adalah 20-35 tahun yaitu $72 \%$. Pendidikan terakhir ibu sebagian besar diambil sebagai sampel ibu dengan pendidikan terakhir SMA dan SMP yaitu SMP berjumlah $36,4 \%$ dan SMA berjumlah $37,7 \%$. Anak keberapa dalam penelitian ini mayoritas adalah anak ke 1 yaitu $32,5 \%$ dan ke 2 yaitu berjumlah $32,5 \%$. Ibu dengan riwayat anemia saat hamil $20.8 \%$. Balita dengan riwayat tidak ASI eksklusif $30 \%$. Ibu yang bekerja terdapat $30.5 \%$.

Tabel 2.

Hubungan Antara Faktor lbu Dengan Kejadian Stunting

\begin{tabular}{|c|c|c|c|c|c|}
\hline \multirow{3}{*}{ Faktor lbu } & \multicolumn{4}{|c|}{ Stunting } & \multirow{3}{*}{ Value $(p)$} \\
\hline & \multicolumn{2}{|c|}{ Stunting } & \multicolumn{2}{|c|}{ Non stunting } & \\
\hline & $\mathbf{F}$ & $\%$ & $F$ & $\%$ & \\
\hline \multicolumn{6}{|l|}{ Usia Ibu Saat Hamil } \\
\hline$<20$ tahun & 10 & 13.0 & 6 & 7.8 & \multirow{3}{*}{, $495^{\star}$} \\
\hline 20-35 tahun & 55 & 71.4 & 56 & 72.7 & \\
\hline$>35$ tahun & 12 & 15.6 & 15 & 19.5 & \\
\hline \multicolumn{6}{|l|}{ Pendidikan lbu } \\
\hline Tidak Sekolah & 0 & 0 & 0 & 0 & \multirow{5}{*}{, $720^{*}$} \\
\hline SD & 16 & 20.8 & 11 & 14.2 & \\
\hline SMP & 26 & 33.8 & 30 & 39.0 & \\
\hline SMA & 28 & 36.4 & 30 & 39.0 & \\
\hline PT & 7 & 9.0 & 6 & 7.8 & \\
\hline \multicolumn{6}{|l|}{ Anak Keberapa } \\
\hline 1 & 27 & 35.0 & 23 & 29.9 & \multirow{6}{*}{, $865^{\star}$} \\
\hline 2 & 24 & 31.2 & 26 & 33.7 & \\
\hline 3 & 16 & 20.8 & 16 & 20.8 & \\
\hline 4 & 7 & 9.1 & 7 & 9.1 & \\
\hline 5 & 2 & 2.6 & 5 & 6.5 & \\
\hline 6 & 1 & 1.3 & 0 & 0 & \\
\hline \multicolumn{6}{|c|}{ Riwayat Anemia Saat Hamil } \\
\hline Anemia & 19 & 24.7 & 13 & 16.9 & \multirow{2}{*}{, $321^{*}$} \\
\hline Tidak anemia & 58 & 75.3 & 64 & 83.1 & \\
\hline \multicolumn{6}{|l|}{ Asi eksklusif } \\
\hline Asi eksklusif & 57 & 74.0 & 51 & 66.2 & \multirow{3}{*}{, $379^{*}$} \\
\hline Tidak ASI eksklusif & 20 & 26.0 & 26 & 33.8 & \\
\hline \multicolumn{5}{|l|}{ Pekerjaan ibu } & \\
\hline Bekerja & 31 & 40.2 & 16 & 20.8 & \multirow{2}{*}{$0.009^{*}$} \\
\hline Tidak bekerja & 46 & 59.8 & 61 & 79.2 & \\
\hline
\end{tabular}

Keterangan: *:Chi-Square

Berdasarkan tabel 2 dari 154 responden Hasil penelitian menunjukkan bahwa tidak terdapat hubungan dan risiko yang signifikan antara usia ibu, pendidikan ibu, anak keberapa, riwayat ASI eksklusif, riwayat anemia pada ibu hamil terhadap kejadian dengan diperoleh nilai $p>0,05$ dari masing-masing varibel, dan terdapat hubungan antara pekerjaan ibu terhadap kejadian stunting dengan nilai $p<0,05(p=0,009<0,05)$. 
Tabel 3.

Risiko Faktor Ibu Terhadap Kejadian Stunting

\begin{tabular}{lccc}
\hline \multicolumn{1}{c}{$\begin{array}{c}\text { Karakteristik } \\
(\mathrm{N}=154)\end{array}$} & OR & \multicolumn{2}{c}{$\mathbf{9 5 \%}$ Confidence Interval } \\
\cline { 3 - 4 } & & Lower & Upper \\
\hline Usia Ibu Saat Hamil & .944 & .486 & 1.836 \\
Pendidikan Ibu & 1.200 & .384 & 3.748 \\
Pekerjaan Ibu & 2.569 & 1.258 & 5.249 \\
Pemberian ASI Eksklusif & 1.425 & .712 & 2.851 \\
Anak keberapa & .844 & .436 & 1.633 \\
Anemia Pada Kehamilan & 1.727 & .789 & 3.784 \\
\hline
\end{tabular}

Berdasarkan Tabel 3 menunjukkan bahwa uji faktor risiko (OR) menggunakan chi-square didapatkan variabel yang paling berisiko terhadapKejadian Stunting adalah variabel pekerjaan ibu dengan nilai OR 2.569.

\section{PEMBAHASAN}

\section{Risiko Usia Ibu Hamil Terhadap Kejadian Stunting}

Hasil penelitian yang diperoleh tidak terdapat hubungan antara usia ibu saat hamil terhadap kejadian stunting dan variabel usia ibu saat hamil $<20$ tahun dan $>35$ tahun memiliki resiko sebesar 0,9 kali terjadinya stunting dibanding usia ibu hamil 20-35 tahun. penelitian ini tidak sejalan dengan penelitian Mira sani dkk (2019) yang menyatakan bahwa usia ibu hamil memiliki hubungan terhadap kejadian stunting hal ini juga dapat dipengaruhi sampel pada penelitian ini yang mayoritas pada usia ibu hamil 20-35 tahun. Adapun penelitian lainnya yaitu menurut Irma (2019) bahwa usia kurang dari 20 tahun tidak serta signifikan mempunyai hubungan terhadap kejadian stunting, akan tetapi usia yang berisiko memiliki peluang sebanyak 2,082 kali terhadap kejadian stunting pada balita. ${ }^{10,11}$

Penelitian ini ibu hamil berusia $<20$ tahun atau $>35$ tahun tidak selalu memiliki balita stunting, karena usia ibu saat hamil merupakan penyebab dasar dari masalah kurang gizi, dan masih banyak faktor-faktor lain yang dapat mempengaruhi terjadinya stunting. Berdasarkan penelitian Kholia dkk bahwa stunting tidak berhubungan dengan usia ibu hamil dapat terjadi karena usia ibu merupakan faktor tidak langsung yang mempengaruhi terjadi stunting dan juga ada faktor lain yang lebih mempengaruh terhadap status gizi faktor-faktor yang mempengaruhi status gizi asupan makanan (energi dan protein), riwayat penyakit infeksi, dan faktor tidak langsung seperti riwayat berat lahir, status ekonomi dan pemberian ASI eksklusif, selain itu pada penelitian ini usia ibu saat hamil $<20$ tahun dan $>35$ tahun ada yang memiliki balita tidak stunting hal ini karena status kesehatan anak dapat dipengaruhi oleh status gizi calon ibu sebelum terjadinya konsepsi, jika asupan gizi calon ibu memadai maka petumbuhan organ-organ tubuh dan fungsi reproduksi dapat berkembang dengan baik sehingga dapat mempengaruhi status gizi bayi yang akan dilahirkan. ${ }^{12,13}$

Hasil penelitian lain yaitu menurut Larasati (2018) bahwa ibu yang hamil pada usia < 20 tahun terdapat balita stunting lebih tinggi di banding balita non stunting. ${ }^{14}$

Ibu yang hamil di usia muda (remaja) berhubungan dengan kelahiran premature adalah pasokan darah ke uterus belum sepenuhnya berkembang dengan baik pada beberapa remaja menyebabkan aliran nutrisi ke janin tidak baik dan pada saat remaja merupakan masa pertumbuhan sehingga terjadi perebutan gizi antara janin dan metabolisme ibu yang menyebabkan janin kekurangan gizi yang dapat mengganggu pertumbuhan dan perkembangan janin yang dapat menyebabkan berat bayi lahir rendah, berat bayi lahir rendahpun salah satu faktor yang memperbesar terjadi stunting, maka dari itu pentingnya promosi kesehatan mengenai risiko tinggi pada kehamilan dan usia yang baik untuk ibu hamil. ${ }^{15}$

Usia ibu hamil sebaiknya tidak terlalu muda dan tidak terlalu tua, usia saat hamil kurang dari 20 tahun atau lebih dari 35 tahun merupakan risiko tinggi untuk ibu dan juga janin. ${ }^{16}$

\section{Risiko Pendidikan lbu Terhadap Kejadian Stunting}

Tidak terdapat hubungan pendidikan ibu terhadap kejadian stunting dan variabel pendidikan ibu rendah s/d SMA memiliki resiko sebesar 1,2 kali terjadinya stunting dibanding pendidikan ibu perguruan tinggi. Hal ini tidak sejalan dengan penelitian Muhammad dkk (2020) manyatakan bahwa terdapat hubungan yang signifikan antara pekerjaan ibu terhadap kejadian stunting dikarenakan pendidikan ibu berkaitan erat dengan 


\section{JKM (Jurnal Kebidanan Malahayati),Vol 7,No.4.Oktober 2021, \\ ISSN (Print) 2476-8944 ISSN (Online) 2579-762X, Hal 842-850}

pengetahuan, biasanya ibu yang berpendidikan tinggi lebih mudah menyerap informasi dibanding ibu yang berpendidikan rendah, namun hasil penelitian dari Cholifatun (2015) menunjukkan bahwa tidak ada hubungan pendidikan ibu terhadap kejadian stunting, hal ini dapat dipengaruhi oleh informasi yang didapatkan ibu tentang nutrisi yang sudah cukup sehingga Pendidikan rendah jika diberi informasi yang memadai dan terus menerus akan memiliki pengetahuan yang cukup mengenai pentingnya nutrisi pada anak. ${ }^{17,18,19}$

Penelitian ini ibu yang memiliki tingkat pendidikan rendah tidak selalu memiliki balita stunting hal ini dikarenakan ada faktor lain yang merupakan penyebab stunting. Kejadian stunting pada balita terkait dengan asupan gizi, asupan gizi yang dimakan oleh anak sehari-hari tergantung pada ibunya sehingga ibu memiliki peran penting terhadap pemenuhan gizi pada balita. Hasil penelitian ini didapatkan bahwa masih banyak ibu dengan pendidikan tinggi namun memiliki anak stunting, hal ini dapat dipengaruhi oleh salah satunya ibu yang bekerja. Ibu yang berkarier tidak semua dapat membagi waktu pada anak dan pada pekerjaan sehingga jika ibu tidak dapat membagi waktunya ibu tersebut akan memiliki waktu sedikit untuk mengasuh anaknya sehingga perawatan anak diserahkan kepada pengasuh yang belum tentu memiliki pengetahuan yang cukup baik. ${ }^{20}$

Tingkat pengetahuan ibu yang tinggi tidak selalu menjamin memiliki balita dengan status gizi yang normal, sehingga ibu yang memiliki pengetahuan yang baik diharapkan mampu mengaplikasikan pengetahuan yang dimiliki dalam kehidupan sehari-hari.

\section{Risiko Anak Keberapa Terhadap Kejadian Stunting}

Tidak terdapat hubungan anak keberapa terhadap kejadian stunting dan variabel anak ke $>2$ memiliki resiko sebesar 0,9 kali terjadinya stunting dibanding anak ke 1 dan ke 2. Hal ini tidak sama dengan hasil penelitian Inochi (2017) menunjukkan bahwa balita yang memiliki ibu dengan jumlah anak sedikit mempunyai risiko mengalami stunting 3,25 kali lebih besar dibanding dengan balita yang memiliki ibu dengan jumlah anak yang banyak, dan pada penelitian farmarida dkk bahwa stunting secara tidak langsung dipengaruhi jumlah anak $>2$. Hasil penelitian lain menurut Agustina bahwa paritas memiliki hubungan yang tidak signifikan terhadap stunting dan bukan merupakan faktor risiko terjadi stunting. Paritas merujuk pada seberapa sering seorang ibu melahirkan anak, frekuensi ibu melahirkan memang memiliki kaitan banyaknya jumlah anak dan tidak berkaitan langsung dengan stunting. ${ }^{21,22}$

Hasil penelitian ini menunjukkan tidak ada hubungan anak keberapa terhadap kejadian stunting, hal ini disebabkan anak ke berapa berkaitan seberapa sering ibu melahirkan yang akan mempengaruhi pengetahuan dan pengalaman ibu namun walaupun demikian ibu yang memiliki anak yang sedikit jika mendapatkan informasi yang cukup tentang pentingnya gizi pada 1000 HPK maka pengetahuan ibupun akan baik, selain itu ada faktor lain karena anak ke berapa merupakan faktor tidak langsung sehingga ada faktor lain yang dapat mempengaruhi stunting, seperti status ekonomi yang baik akan mempengaruhi kualitas dan kuantitas makanan yang di konsumsi oleh keluarga. 23

Hasil penelitian ini didapatkan juga balita dengan anak ke 1 dan 2 namun banyak tidak mengalami stunting, hal ini dapat dipengaruhi oleh sampel penelitian ini mayoritas anak ke-1 dan ke-2, dan selain itu faktor lainnya yaitu sanitasi lingkungan, sanitasi lingkungan yang buruk dapat memicu timbulnya penyakit infeksi (misalnya diare dan cacingan) yang dapat mengganggu penyerapan nutrisi pada sistem pencernaan sehingga mengakibakan kekurangan gizi pada anak. ${ }^{24,20,25,26}$

\section{Risiko Riwayat Anemia Ibu Saat Hamil Terhadap Kejadian Stunting}

Tidak terdapat hubungan anemia terhadap kejadian stunting dan variabel riwayat anemia ibu saat hamil memiliki resiko sebesar 1,7 kali terjadinya stunting dibanding ibu dengan riwayat tidak anemia saat hamil, , hal ini dapat dipengaruhi oleh jumlah sampel pada penelitian ini mayoritas ibu dengan riwayat tidak anemia saat hamil. Hasil penelitian ini sejalan dengan penelitian Kristiana (2016) menunjukkan bahwa ibu yang anemia saat hamil berisiko 1,5 kali lebih tinggi anaknya kan menderita stunting di banding dengan ibu hamil tidak anemia. ${ }^{27}$

Seorang ibu hamil yang tidak tercukupi zat gizinya akan mengalami anemia, ibu anemia saat hamil akan meningkatkan risiko berat bayi lahir rendah, BBLR sendiri akan meningkatkan risiko terjadinya stunting pada balita. Ibu anemia saat hamil tidak selalu memiliki anak stunting hal ini dapat dipengaruhi oleh kecukupan gizi bayi setelah lahir, seperti setelah bayi lahir diberikan ASI eksklusif, setelah 6 bulan diberikan MPASI yang baik dan imunisasi lengkap serta sanitasi lingkungan yang baik, beberapa hal tersebut dapat mencukupi kebutuhan nutrizi yang akan mebantu 
tumbuh kembang anak selama 1000 HPK sehingga anak dapat tumbuh dan berkembang secara optimal begitupun sebaliknya ibu yang tidak anemia saat hamil namun masih sering memiliki anak stunting ini dapat disebabkan oleh faktor lain seperti kurangnya gizi makronutrien dan mikronutrien lainnya selain dari zat besi yang dapat menghambat tumbuh kembang pada anak. ${ }^{20,24,28}$

\section{Risiko ASI Eksklusif Terhadap Kejadian Stunting}

Tidak terdapat hubungan ASI eksklusif terhadap kejadian stunting dan balita dengan riwayat tidak ASI eksklusif memiliki resiko sebesar 1,4 kali terjadinya stunting dibanding balita dengan riwayat ASI eksklusif. Hal ini tidak sejalan dengan hasil penelitian Sofia (2019) menunjukkan bahwa terdapat hubungan ASI eksklusif terhadap kejadian stunting, hal ini dapat dipengaruhi oleh jumlah sampel pada penelitian yang mayoritas balita dengan riwayat $\mathrm{ASI}$ eksklusif.

Berdasarkan dalam penelitian ini balita dengan riwayat $\mathrm{ASI}$ eksklusif tidak selalu bertumbuh dan berkembang secara normal (non stunting) namun ada juga yang mengalami stunting hal ini juga dapat disebabkan oleh kualitas dan volume ASI, kualitas ASI yang baik dipengaruhi oleh makanan ibu, asupan makanan ibu dengan kandungan zat gizi makro yang akan berubah menjadi cairan ASI ketika makanan dicerna di dalam tubuh lalu dibawa oleh darah menuju keseluruh tubuh dan salah satunya tempat pemberhentian zat gizi tersebut adalah kantung ASI. Asupan zat gizi makro makanan selama menyusui perlu ditingkatkan karena pada ibu menyusi membutuhkan energi yang ekstra dalam pembentukan ASI, kebanyakan bayi cepat lapar agar kalori yang keluar tersebut seimbang maka diperlukan asupan makanan dengan gizi seimbang untuk pembentukan ASI, sehingga jika volume ASI mencukupi kebutuhan bayi dan kualitas ASI baik akan membantu tumbuh kembang pada bayi begitupun sebaliknya walaupun pemberian ASI eksklusif namun kualitas ASI kurang baik dan volume tidak mencukupi kebutuhan bayi maka akan menghambat tumbuh kembang pada bayi selain itu dapat dipengaruhi juga pemberian MPASI yang tidak mencukupi kebutuhan gizi setelah bayi berusia 6 bulan sehingga gizi pada 1000 HPK tidak terpenuhi yang dapat mengakibatkan terjadinya stunting. 29,30

ASI merupakan makanan pertama dan utama pada bayi, ASI adalah makanan yang terbaik untuk bayi karena mengandung semua nutrisi yang dibutuhkan bayi dan zat pelindung dari berbagai kuman. ASI juga membantu pertumbuhan bayi sehingga menjadikan bayi lebih sehat dan cerdas. ASI eksklusif adalah pemberian ASI saja tanpa tambahan cairan lainnya. Sebelum 6 bulan sistem pencernaan bayi belum mampu berfungsi dengan sempurna, sehingga ia belum mampu mencerna makanan selain ASI. Pemberian ASI yang kurang menyebabkan bayi kekuragan gizi yang akan berdampak pada gangguan psikomotor, kognitif dan sosial serta secara klinis menggangu pertumbuhan. Pertumbuhan dan perkembangan masa bayi membutuhan masukkan zat gizi yang seimbang,namun kemampuan bayi untuk makan dibatasi oleh keadaan sistem pencernaan yang masih dalam tahap pematangan. Satu-satunya makanan yang sesuai dengan keadaan sistem pencernaan bayi dan memenuhi kebutuhan gizi adalah ASI. ${ }^{31}$

\section{Risiko Pekerjaan Ibu Terhadap Kejadian Stunting}

Terdapat hubungan pekerjaan ibu terhadap kejadian stunting dan ibu yang bekerja memiliki resiko sebesar 2,6 kali terjadi stunting dibanding ibu yang tidak bekerja. Hal ini sejalan dengan penelitian Afiska dkk (2019) menunjukkan bahwa terdapat hubungan pekerjaan terhadap kejadian stunting. Faktor ibu yang bekerja bukan penyebab utama masalah gizi pada anak namun pekerjaan ini lebih disebut sebagai faktor yang mempengaruhi dalam pemberian makanan. Hal ini disebabkan karena tidak semua ibu yang bekerja dapat membagi waktu antara pekerjaan dan waktu untuk merawat anak dan cenderung ibu yang bekerja di luar rumah memiliki waktu yang sedikit untuk anaknya sehingga pola asuh diberikan kepada orang lain seperti nenek, saudara lainnya yang belum tentu pengetahuannya cukup baik mengenai pola asuh dan status gizi. Hasil penelitian lain didapatkan bahwa ibu yang bekerja memiliki anak yang stunting lebih sedikit dibanding ibu yang tidak bekerja, hal ini disebabkan karena ibu yang bekerja akan membantu status ekonomi sehingga kebutuhan keluarga tercukupi dan juga dapat dipengaruhi oleh ibu yang dapat menjalankan peran ganda seperti ibu dapat membagi waktu antara bekerja dan merawat anak sehingga kedua peran tersebut dapat berjalan dengan baik. 20,32

Pekerjaan merupakan faktor penting dalam menentukan kualitas dan kuantitas pangan, karena pekerjaan berhubungan dengan pendapatan, apabila pendapatan meningkat maka kesehatan dan masalah keluarga yang berkaitan dengan status gizi mengalami perbaikan, namun seorang anak usia 0-5 tahun masih sangat bergantung 


\section{JKM (Jurnal Kebidanan Malahayati),Vol 7,No.4.Oktober 2021, \\ ISSN (Print) 2476-8944 ISSN (Online) 2579-762X, Hal 842-850}

dengan ibunya. Balita masih perlu bantuan dari orangtuanya untuk melakukan tugas pribadinya sehingga pekerjaan dapat disebut sebagai faktor yang mempengaruhi dalam pemberian makanan, zat gizi, pengasuhan dan perawatan anak. ${ }^{20}$

Gizi yang baik tidak hanya dilihat dari kuantitas makanan namun diperhatikan juga kualitas makanan. Keragaman makanan merupakan gambaran kualitas makanan yang di konsumsi oleh balita, keragaman makanan merupakan salah satu masalah gizi utama di negara berkembang seperti Indonesia, pada negara berkembang di dominasi makanan sumber kalori dan kurangnya asupan makanan hewani, buahbuahan dan sayuran. Beberapa hasil penelitian menunjukkan bahwa keragaman makanan berhubungan dengan stunting, Sehingga pengetahuan orang yang mewarawat anak sangat berpengaruh pada tumbuh kembang anak, oleh sebab itu ibu yang bekerja harus tetap memilih seseorang yang berpengetahuan baik untuk mengasuh anaknya serta diharapkan dapat meneliti lebih lanjut mengenai jenis pekerjaan seperti apa yang dapat mempengaruhi stunting. ${ }^{33}$

\section{SIMPULAN}

Tidak terdapat hubungan dan tidak terdapat risiko yang signifikan antara usia ibu, pendidikan ibu, anak keberapa, riwayat ASI eksklusif, riwayat anemia pada ibu hamil terhadap kejadian stunting menggunakan uji chi-square dengan diperoleh nilai $p>0,05$ dari masing-masing varibel, dan terdapat hubungan antara pekerjaan ibu terhadap kejadian stunting dengan diperoleh nilai $p<0,05$ serta terdapat besar risiko ibu yang bekerja terhadap kejadian stunting yaitu memiliki resiko sebesar 2,6 kali dibanding ibu yang tidak bekerja.

\section{SARAN}

Peneliti selanjutnya diharapkan dapat meneliti lebih lanjut mengenai jenis pekerjaan ibu seperti apa yang dapat mempengaruhi stunting dan mengkaji lebih mendalam mengenai pola asuh anak diserahkan kepada siapa dan pendidikan terakhir pengasuh dari anak tersebut, bukan hanya pendidikan terakhir dari ibunya.

\section{DAFTAR PUSTAKA}

World Health Organization, 2018.Reducing stunting in children: equity considerations for achieving the global targets 2025 .

Kemenkes RI, 2018. Hasil Utama Riset Kesehatan Dasar Tahun 2018. Kementrian Kesehat Republik Indonesia.

PKM FK UKI, 2018. Gambaran Prevalensi dan
Karakteristik Balita dengan Stunting Pada 10 Desa Kabupaten Sumedang Tahun 2018.

Khairani, Nurul SUE, 2019. Family characteristics as risk factors of stunting among children age 12-59 month. Fam Charact as risk factors stunting among Child age 12-59 Mon.4(2).

Eko,Setiawan, Machmud R, Masrul M, 2018. Faktor-Faktor yang Berhubungan dengan Kejadian Stunting pada Anak Usia 24-59 Bulan di Wilayah Kerja Puskesmas Andalas Kecamatan Padang Timur Kota Padang Tahun 2018. J Kesehat Andalas.

Evi, Kusumawati, Rahardjo S, Sari HP,2019. Model Pengendalian Faktor Risiko Stunting pada Anak Bawah Tiga Tahun. Kesmas Natl Public Heal J. 2015.

W yuliana Dkk. Darurat Stunting dengan Melibatkan Keluarga. In: Darurat Stunting dengan Melibatkan Keluarga. Ed.Ke-1. Sulawesi Selatan,Yayasan Ahmar Cendekia Indonesia.

Sabrina, Cut Mutiara, Joserizal Serudji AA, 2017. Gambaran Anemia Pada Kehamilan Di Bagian Obstetri Dan Ginekologi RSUP Dr. M. Djamil Padang Periode 1 Januari 2012 sampai 31 Desember 2012, 6(1).

World Health Organization (WHO), 2014. Global Nutrition Targets 2025. Can Pharm J.

Nuraeni, Indah, Diana H, 2019. Karakteristik Ibu Hamil Dan Kaitannya Dengan Kejadian Stunting Pada Balita Di Kecamatan Tamansari Kota Tasikmalaya. Media Inf, 15(1), 10-5.

Asiah N, Birwin A. Hubungan Faktor lbu Dengan Kejadian Stunting. Pros Semin Nas Dan ... [Internet]. 2019;1(3):189-97. Available from: https://proceedings.uhamka.ac.id/index.php/ semnas/article/view/171

Temanggung $K$. Journal of nutrition. Nature. 1959;184(4681):156.

Larasati DA, Nindya TS, Arief YS, 2018). Hubungan antara Kehamilan Remaja dan Riwayat Pemberian ASI Dengan Kejadian Stunting pada Balita di Wilayah Kerja Puskesmas Pujon Kabupaten Malang. Amerta Nutr, 2(4):392.

Irwansyah I, Ismail D, Hakimi M. Kehamilan remaja dan kejadian stunting anak usia $6-23$ bulan di Lombok Barat.

Dr. Siswosuharjo, Suwignyo Sp.OG. MK dkk, 2011. Panduan Super Lengkap Hamil Sehat. In: Panduan Super Lengkap Hamil Sehat. Ed.Ke-1. Semarang: PT.Niaga Swadaya, 145 .

Lailatul Muhammad, Ni'mah. C, 2015. Hubungan 
Tingkat Pendidikan, Tingkat Pengetahuan dan Pola Asuh lbu dengan Wasting dan Stunting pada Balita Keluarga Miskin. Media Gizi Indones, 10, 84-90.

Fajrina N, Syaifudin, 2016. Hubungan Faktor Ibu Dengan Kejadian Stunting Pada Balita Di Puskesmas Piyungan Kabupaten Bantul. Fak IImu Kesehat Univ 'Aisyiyah Yogyakarta,10.

Aprilia, Dewi P, Ariski TN, Kumalasari D, 2019. Faktor-faktor yang Berhubungan dengan Kejadian Stunting pada Balita 24-36 Bulan di Wilayah Kerja UPT Puskesmas Gadingrejo Kabupaten Pringsewu. Wellness Heal Mag [Internet],1(Agustus):231-7. Available from: http://wellness.journalpress.id/index.php/well ness/

Palino I, Majid R, ainurafiq A, 2017. Determinan Kejadian Stunting pada Balita Usia 12-59 Bulan di Wilayah Kerja Puskesmas Puuwatu Kota Kendari Tahun 2016. J IIm Mhs Kesehat Masy Unsyiah, 2(6):186866.

Setia A, 2015). Faktor Risiko Kejadian Stunting Pada Batita Usia 6 - 36 Bulan Di Desa Fatukanutu Kecamatan Amabi Oefeto Kabupaten Kupang. Kesehat Gizi, 505-159.

Casnuri C, Widaryanti R, 2016. Hubungan Pengetahuan Ibu Tentang

Sibling Rivalry Dengan Pola Asuh Orang Tua Terhadap Anak Di Padukuhan Gude Dan Pakwungu. ... Dunia D-lii ... [Internet], (35):61-70. Available from: http://ejournal.annurpurwodadi.ac.id/index.ph p/TSCD3Kep/article /view/105

Zairinayati RP, 2019). Hubungan Hygiene Sanitasi dan Lingkungan dengan Kejadian Stunting Pada Balita. J IIm Multi Sci Kesehat,10(1):78-91.

Azwar LM, Putra EV, Selinaswati, 2020. Pola Asuh Ibu Bekerja (Studi Kasus: 5 Keluarga Ibu Bekerja Pengisi Polybag di CV. Tani Subur
Jorong Cubadak Nagari Cubadak Kecamatan Lima Kaum Kabupaten Tanah Datar. J Perspekt J Kaji Sosiol dan Pendidik, 3(2):326-32.

Rahmayana, Ibrahim IA, Darmayati DS, 2014. Hubungan Pola Asuh Ibu Dengan Kejadian Stunting Anak Usia 24-59 Bulan Di Posyandu Asoka II Wilayah Pesisir Kelurahan Ba- rombong Kecamatan Tamalate Kota Makassar Tahun 2014. Public Heal Sci J, VI(2):424-36.

Warsini KT, Hadi H, Nurdiati DS, 2016. Riwayat KEK dan anemia pada ibu hamil tidak berhubungan dengan kejadian stunting pada anak usia 6-23 bulan di Kecamatan Sedayu, Bantul, Yogyakarta CED and maternal anemia did not associate with stunting in children 6-23 months in Sedayu Subdistrict, Bantu,(44).

Prihutama NY, Rahmadi FA, Hardaningsih G, 2018. Pemberian Makanan Pendamping Asi Dini Sebagai Faktor Risiko Kejadian Stunting Pada Anak Usia 2-3 Tahun. Diponegoro Med J (Jurnal Kedokt Diponegoro),7(2):1419-30.

Wijayanti F, Pramulya S I, Saparwati M, 2020). Hubungan Pemberian Asi Eksklusif Dengan Kejadian Stunting Pada Balita Usia 24-60 Bulan. J Kesehat Kusuma Husada, 35-41.

Linda, Edita, 2019. ASI Eksklusif. In: Wirdiyanto T, editor. ASI EKSKLUSIF. Ed.Ke-1. Cilacap: Yayasan Famiul Jawaid.

Utami, Puji ,2015. Pekerjaan Ibu Di Luar Rumah Dan Tinggi Badan lbu Bapak Pendek Sebagai Faktor Resiko Kejadian Stunting Pada Anak Sekolah Dasar Di Kabupaten Pemalang, 46:56.

Widyaningsih NN, Kusnandar K, Anantanyu S, 2018). Keragaman Pangan, Pola Asuh Makan Dan Kejadian Stunting Pada Balita Usia 24-59 Bulan. J Gizi Indones (The Indones J Nutr, 7(1):22-9. 